\title{
Ethnic Cultural and Religious Practices of Migrant Women in the Republic of Tatarstan
}

\author{
Tatyana A. Titova ${ }^{1}$, Vadim E. Kozlov ${ }^{1} \&$ Elena V. Frolova ${ }^{1}$ \\ ${ }^{1}$ Kazan (Volga Region) Federal University, Kazan, Russia \\ Correspondence: Elena Valeryevna Frolova, Kazan (Volga Region) Federal University, Kremlyovskaya Street 18, \\ Kazan 420008, Russia. E-mail: elenaieup@mail.ru
}

Received: April 14, 2015 Accepted: April 20, 2015 Online Published: April 27, 2015

doi:10.5539/jsd.v8n4p177 URL: http://dx.doi.org/10.5539/jsd.v8n4p177

\begin{abstract}
The applicability of the research is ridden by necessity of exploring the various aspects of labor migration, which has an exceptional social, political and cultural significance in the modern world. The aim of the study is to analyze the ethnic, cultural and religious practices of migrant women in the Republic of Tatarstan. The analyzed material was obtained with help of methods of mass survey, as well as a biographical and semi-structured interview. As a result, the systematization of the data revealed the features of social communication of migrant women, ranked the structure of the social identity of respondents, analyzed their cultural linguistic competence as well as the degree of actualization of the confessional aspect of identity. The article may be useful to ethnologists, social and cultural anthropologists, political analysts, and representatives of the bodies supervising migration policy and inter-ethnic cooperation.
\end{abstract}

Keywords: migration, social interaction, social identity, ethnic identity, confessional identity, linguistic competence, adaptation

\section{Introduction}

\subsection{The Applicability of the Research}

Labor migration is of exceptional economic, social, political and cultural significance in the modern world. Developed transportation facilities, advance in capitalist relations and open borders turned out to be the terms of exercising the human right to freedom of movement and change one's way of life. Today, labor migration is one of the main channels of social mobility. Migration processes take a central position on the agenda of the state policy, media, and academic symposia. Migration has become not only a part of everyday and professional life of people, but also formed a wide range of concerns and part of the topical issues, which studying and solving seems promising.

\subsection{A Review of Research on the Topic}

It has long been considered that only men were coming to find some job, and women were "secondary" or dependent migrants (Tyuryukanova, 2000). In the perception of the majority of the host country the portrait of the average migrant is drawn exclusively as of man's. Migrant women had long been accepted as "invisible workers".

Referring to the study of migrant women is caused by transformation of the structure of migration flows: if a few years ago mostly men were coming in search of work, in recent years the number of women labor migrants has increased significantly.

According to experts, women represent $25-30 \%$ of labor migrants, i.e. about $1.5-2$ million people (Ilmbetova, 2013). They are mainly immigrants from former Soviet Union republics: the CIS countries dominate the regions of origin of migrants (about $3 / 4$ of the entire labor migration in Russia) (Female migrants from the CIS countries in Russia, 2011). According to the Center for Migration Studies, in 2010, $30.2 \%$ of women came from Uzbekistan, 9.0\% - from Kazakhstan, 13\% - from Kyrgyzstan, 14\% - from China, 13\% - from Ukraine (Abashin, 2007 - 2008 Ilimbetova, 2013). Working in Russia women are among the most economically active age group: 20 to 50 years (about 92\%) (Female migrants from the CIS countries in Russia, 2011). 
Many studies have focused on the origin and forms of labor migration of women, as well as its consequences and risks, associated with a change of residence and civil status. As for difficulties associated with migration of women, researchers give special priority to human trafficking, slave labor, physical abuse, humiliation and discrimination (Migration and Security in Russia, 2000). In addition, leaving their country women have to face the loss of the job and pension benefits, emotional alienation from their relatives and family disruption (Ilimbetova, 2013, Grishunina, 2011).

Since the migration, including labor and women's, exists not only in legal, but also in illegal / semi-legal forms, it is difficult to study: a simple statistical calculation of the number of migrant women and their principal socio-demographic characteristics (age, marital status, level of education and et al.) is sometimes even not possible (Chudinovskikh, 2004).

Despite the ambitious life strategy - a choice in favor of migration, employment, (often) an independent life away from their families - the majority of women migrants, especially from Central Asia and the Caucasus, have conventional views on family and gender roles.

The feminization of migration can be considered by the host country as a challenge, as female migration is accompanied by a number of factors (e.g., higher rate of informal employment, cultural ethnic practices) which may affect the structure of society itself.

\section{Materials and Methods}

\subsection{The Purpose and Objectives of the Study}

The purpose of the study is a comprehensive analysis of cultural ethnic and religious practices among migrant women of the Republic of Tatarstan. Solution of the general research objective is connected with the following range of issues:

- identifying features of social contacts of the respondents;

- analyzing the structure of the social identity of respondents;

- determining the relevance of the confessional aspect to the identity matrix of respondents;

- identifying the respondents' attitudes towards the role of religion in society.

\subsection{Theoretical and Empirical Methods}

The study is based on methodological principles of multiparadigmatic approach. In the context of our study there are two basic tenets of F. Barth's theory: firstly, the conclusion that the determinant for membership in the group are socially set factors, which are based on the categorical attribution but not "objectively" existing cultural differences. Secondly, the ethnic categories, while identifying itself as well as classifying other people of ethnic groups take into account not the amount of objective differences, but only those which individuals themselves accept as significant.

The work is based on the analysis of the empirical material collected in $2013-2014$. The data was collected mainly through observation, semi-structured and biographical interviews. Also there are a mass survey data among women from diasporas. Presentation of the results is based on the principles of the so-called "thick description" that is, a type of analysis carried out in the terms of the informants themselves.

\subsection{Base of Research}

In the survey we interviewed 300 migrant women from the Uzbek, Kyrgyz, Tajik and Azerbaijani population of Tatarstan as well as 20 women of different diasporas.

\section{Results}

\subsection{Characteristics of the Study Subject}

The pollees were divided into two age groups -18 to 30 years (50.7\%) and 31 to 50 years (49.3\%).

Half of Kyrgyz respondents are not married yet, $25 \%$ are married in secular office, other $25 \%$ are married in both secular and religious offices. Most of the Azerbaijan respondents are married in both secular and religious offices. As for Tajik and Uzbek women respondents, many of their marriages are on the basis of religion. The fact of being married according to common-law is confirmed by $15 \%$ of Tajik and $25 \%$ of Uzbek women. For comparison, this applies to $5 \%$ of Azerbaijan women and to $0 \%$ of Kyrgyz women - none of the respondents said that she was married according to religious rules. It should be noted that divorce is not typical for any of the groups surveyed: the number of divorced women does not exceed 5\% in each of the nationalities.

About $30 \%$ of all women surveyed have been living in Tatarstan for 3 to 5 years. $25 \%$ of respondents said about 
a longer period of time - 5 to 10 years. Slightly fewer respondents have been residing in Tatarstan for relatively short period -1 to 3 years. About $5 \%$ of respondents said that they were born in Tatarstan and have been living here for life.

About $60 \%$ of women migrants said they did not plan to move. Most of those who expressed this opinion have been living in Tatarstan for 3 to 10 years. $20 \%$ of respondents said that they were going to leave Tatarstan. Most of them have been living in Tatarstan for 1 to 5 years.

From the interview: "I have never thought that I would go to Russia and live here, I did not think about it at all. In Turkmenistan, I gave birth to children and did not think that it would. Happen. When we were living here at that time and working, we were considering moving all the time, but we've been here for 18 years already." (female, Uzbek, 55 years old).

Kyrgyz and Azerbaijani representatives have more desire to move. $30 \%$ of them say that they were going to move out of Tatarstan. Most of Uzbek and Tajik interviewees, on the contrary, want to stay in here. More than half of them said they were not going to leave Tatarstan in the nearest future.

\subsection{Economic Aspects of Female Labor Migration}

The employment issues are the main reason of moving, said respondents. The respondents said that they were not satisfied with low wages and the threat of unemployment was frightening. According to the study, the Azerbaijani and Tajik representatives are concerned mostly with low wages, and Uzbek representatives are concerned mostly with unemployment. Among the Kyrgyz respondents, a common reason impelling them to leave Tatarstan is difficulty in adapting to the new conditions of life. Quite often respondents mentioned their desire to live in their homeland as the main cause to leave this region. This view is most prevalent among the Kyrgyz and Uzbek representatives. It is worth saying the Azerbaijani women, compared with others, often consider such factors as the deterioration of cross-ethnic relations, infringement of the rights of national minorities and the adoption of laws encroaching on human rights in general as the main cause of moving.

Alignment of answers to the question, revealing the state of labor employment of migrant women in Tatarstan, represents a very diverse picture. The majority of respondents is working in the service sector and holds positions that do not require special skills. The most common is the work of a seller and a conductor. Those who have been living in Tatarstan for 1 to 5 years most often are in this group. Unemployment is mainly characteristic of the respondents living in Tatarstan for 3 to 10 years. Migrant women living in Tatarstan for 5 to 10 years or more consider themselves housewives. Aspiration towards education is mentioned mostly by the respondents living in Tatarstan for 5 to 10 years.

According to the general trend among the Uzbek representatives the most common occupations are a seller (40\%) and a conductor $(40 \%)$. More than $20 \%$ of the Uzbek respondents said that they were not working. It explains why the Uzbek pollees mostly referred to employment as the reason for leaving Tatarstan.

Working as a seller is also most popular among the Kyrgyz migrant women (25\%). But running an individual enterprise is typical for them as well, this job was chosen by $20 \%$ of Kyrgyz respondents. About $17 \%$ of respondents said that they were acquiring an education.

From the interview: "Our [Kirgiz women] are getting on well here, they got adjusted, all of them gained citizenship long ago." (male, about 28 y.o., Kyrgyz).

Most of Azerbaijani representatives, in contrast to the Uzbek women, do not consider themselves as unemployed.

From the interview: "Azerbaijani female should not serve a strange male. So, she can sell products at the market, but will never sell something to men. Her husband will never allow it." (male, Azerbaijani, 45 y.o.).

Despite the fact that over $20 \%$ of Azerbaijani women are not engaged in formal employment, they see themselves as housewives. Over $20 \%$ of Azerbaijani respondents are acquiring an education, $10 \%$ are working as teachers, another $10 \%$ are sellers.

\subsection{Features of Social Contacts of Migrant Women}

Analysis of the social contacts of the respondents in family relations shows that the determining factor of marital culture of migrant women is nationality of the spouse. Mono-national marriages are dominating among the respondents. Thus, the majority of respondents among Tajik, Uzbek, Azerbaijani and Kyrgyz women are married to representatives of their own nationality. Only $10 \%$ of Tajik women, and about $5 \%$ of Kyrgyz and Azerbaijani women said that are married to men of different nationalities, such as Tatars and a little less Russians. None of Uzbek women said she was married to a man of different nationality. Thus, all representatives of the study 
groups are characterized by a low degree of loyalty to the inter-ethnic marriages.

The results of the study of every day life social contacts of respondents reveal a high degree of intra-group consolidation among representatives of all study groups.

Most of the respondents indicate that communicate with people of their own nationality in the living community: more than $80 \%$ of the Uzbek and Kyrgyz respondents and two thirds among Azerbaijani and Tajik women reported having close continual contacts with representatives of their own ethnic groups; one in ten of Uzbek respondents, one in eight among Kyrgyz women, every fifth among Azerbaijani women and one third of Tajik women reported having occasional contacts.

Analysis of friendly ties of the respondents also confirms that the majority of them are focused on social contacts in mono-ethnic environment. The majority of respondents in all groups say about having friends among the local population. However, over $60 \%$ of Tajik and Kyrgyz women, over $50 \%$ of Azerbaijani and more than $40 \%$ of Uzbek women say that among their friends there are more representatives of their own nationality. One-fifth of Uzbek and Azerbaijani women, one sixth of Tajik and one third of Kyrgyz women say that among their friends there are both Russians and Tatars, and one in ten Uzbek and Kyrgyz, one in eight Azerbaijani and every sixth Tajik women state that they mainly keep in touch with Tatars. It should be noted that the number of respondents who maintain friendly ties with representatives of other nationalities is higher among divorced or not married women.

Every second Uzbek, every tenth Azerbaijani i every tenth, one third of Tajik and one forth of Tajik women say that they have friendly contacts with the local population due to the joint work; one fourth of Uzbek, every second of Azerbaijani and one third of Kyrgyz and Tajik women have them due to joint leisure; 17\% of Azerbaijani and about 4\% Kyrgyz and Tajik women say their communication with local communities is reduced to congratulating each other on common holidays.

However, every tenth from Kyrgyz and Tajik, every ninth from Azerbaijani and every twelfth from Uzbek pollees in critical situations are going to ask for help their friends from local population.

The respondents prefer to maintain the closest friendly ties representatives of their own ethnic groups. Thus, about $90 \%$ of Uzbek, $82.9 \%$ of Kyrgyz, and two-thirds of Azerbaijani and Tajik women say that their best friend is of one nationality with them. Close friendly relations with representatives of other nationalities (primarily with Tatar women) are maintained by every tenth Uzbek, every sixth Kyrgyz, and one fourth of Azerbaijani and Tajik women.

Thus, summarizing the above data it can be stated that more than a half (about 55\%) of respondents from all ethnic groups recognize that representatives of their own nationalities dominate among their friends. In the friendly contacts with representatives of the host population the pollees tend more to communicate with the Tatars which is due to common holidays culture. Friendly ties with the local population are primarily due to joint work and leisure, but often do not involve asking for help in a critical situation.

The results of the study reveal a high degree of intra-group consolidation among the study groups. For most of the women interviewed social contacts are limited to their relatives only. For example, three-quarters of female respondents in all ethnic groups, regardless of period of residence in Tatarstan and marital status, in the first place will address to the relatives in a difficult situation. The option of "addressing to friends" is second, but friendship is much less popular among respondents, compared to family ties: only fifth of Uzbek, Kyrgyz and Azerbaijani and tenth of Tajik women tend to ask friends for help.

The last thing they would do in critical situation was addressing to the community: tenth of Kyrgyz, Azerbaijani and Tajik and third of Uzbek women would do it using up all the possibilities.

These trends, reflecting the desire of predominantly mono-ethnic social contacts, were confirmed as well in the respondents' attitudes to marriages with representatives of other nationalities. So, $87.8 \%$ of Uzbek, $70 \%$ of Azerbaijani, 57.1\% of Tajik and 52.8\% of Kyrgyz women disapprove of marriages of their relatives with representatives of other nationalities. It should be noted that the negative attitude toward inter-ethnic marriages does not depend on the period of residence of the respondents in the region: the number of migrant women who hold this point of view is about the same in groups living in Tatarstan "at least 5 years", "5 to 10 years "and" more than 10 years". Uzbek respondents have the most intransigent attitude to this issue, among whom $70 \%$ of respondents strongly disapprove of inter-ethnic marriages; also there are many respondents who strongly disapprove of marriage with a representative of other nationalities among Azerbaijani women (42.9\%) (and a third of respondents among Tajik and Kyrgyz women). Uzbek and Azerbaijani women turned out to have minimum number of respondents approving of mixed marriages $(1.1 \%$ and $7.1 \%$, respectively), whereas among 
Kyrgyz and Tajik women - a fourth of respondents. It should be noted that among the respondents who express a positive attitude toward intermarriage, women, unmarried or married with registration in the registry office, and not according to religious rules.

Negative attitude toward intermarriage shows also a high level of intra-group cohesion among the study groups and a high level of ethnocentrism.

Thus, the analysis of social contacts of those surveyed in family and marriage and every day life relations, their orientation to the friendly interaction and attitude towards inter-ethnic marriages shows that the dominant strategy among migrant women is the pursuit of a mono-ethnic interaction. The idea of friendly relations with the local population is largely declarative in nature, because it does not suggest using them in a critical situation.

\subsection{The Social Identity of Migrant Women}

In the social identity of Uzbek women religious component is dominating: $96 \%$ of respondents see themselves as Muslim: I.: And what is more important: faith or nationality? P.: Faith, I think faith. The nationality is not important. In general - we all originate from one man. I heard that Adam and Eve had many children, they all always swore to each other. And then one day, the God made all that languages not to be understood, he did it that way - some people were turned into Russians, some - into the French, it was done by Allah as. I heard it." (female, Uzbek, 55 y.o.).

Next are gender and family roles ("woman", "daughter", "wife"). In third place - judgmental characteristics -"hardworking", "smart", "beautiful." Ethnic, civic and professional components of the identity in the identification matrix of Uzbek women are almost not expressed. Third of Kyrgyz respondents noted the importance of family positions ("daughter", "wife"), every tenth sees herself as the representative of the profession, one in seven sees herself as a citizen of the country. One third of Kyrgyz respondents says about the importance of their ethnic identity; fourth of respondents - of their religious identity ("Muslim"). The Azerbaijani women identity consists of the following components: religious identity (57.1\% of respondents), gender identity (woman $-50 \%$ of respondents, wife $-48.6 \%$, daughter $-43.3 \%$ ); ethnic identity $(38.6 \%$ ), professional identity (35.7\%), and civil identity (25.7\%). Tajik women in the first place see themselves as Muslims (52.9\% of respondents), in the second place - representatives of their families - wives and daughters ( $45.7 \%$ and $38.6 \%$, respectively); in the third place - representatives of their nationalities (34.3\%), citizens of the countries $(24.3 \%)$ and a representatives of the professions (18.6\%).

Thus, representatives of all groups are characterized by the dominance of the religious component of identity and roles of family positioning. Wherein Uzbek women have more actualized religious component of identity (more than $90 \%$ of respondents), while Armenian and Tajik women have it at a level of $50 \%$ only.

Migrant women emphasize their religiousness and often show the priority of the religious component over other components of identity.

Professional aspect of identity is mostly expressed by Azerbaijani women, which suggests a greater degree of integration into the host community. Ethnic identity aspect is mostly actualized among Azerbaijani respondents (about 40\%) and less - among Tajik and Kyrgyz women (about one third of respondents).

Speaking about welding signs, playing the role of ethnic determinant for respondents, it should be noted that culture is the most important factor of ethnic integration for migrant women - it was set in the first place by about a half of Uzbek women participated in the study, and third of Tajik, Kyrgyz and Azerbaijani women. The second place is given to such factor of ethnic integration as "homeland, nature" - fourth of Uzbeks and Tajik, one fifth of Azerbaijani and one in two of Kyrgyz women think so. The third position was given to a language - its importance is noted by every tenth among Azerbaijani, one in eight among Uzbek and Tajik, and every twelfth among Kyrgyz women surveyed. Uzbek women referred religion as the most welding factor (fourth of respondents). Subjective relevance of such factor as "historical past" is identified by fifth of Uzbek respondents.

Such welding factors as "traits", "external (physical) appearance," "ethnic identity" were not identified by the majority of respondents as important.

Summarizing all the above, we should note that in the identity matrix of migrant women gender and family roles occupy a significant place. This may be due to the fact that respondents' living space is limited largely to family-related range. In the identity matrix Uzbeks, Azerbaijani women and Tajik women dominated the religious component of identity. Uzbek, Azerbaijani and Tajik women has religious aspect as dominating in their identity matrix. Ethnic aspect of identity is more actualized among Azerbaijani and Kyrgyz women, but, for the majority of respondents in all groups confessional identity is more important than ethnicity. At the same time, the majority of respondents do not tend to evaluate themselves through such individual judgmental characteristics as 
"smart", "beautiful", "hardworking", which are insignificant in the structure of identity of migrant women. This may indicate that in the minds of respondents collectivist values, where man realizes himself first of all as part of a social group, dominate.

Professional aspect of identity in the majority of respondents is not actualized, which may indicate a low degree of integration into the host community. From the interview: "If you have a husband, why should a woman work? Azerbaijani woman can be a teacher or somebody else, but not to serve strange men." (male, 27 y.o., Azerb.).

The findings lead to the conclusion that migrant women are poorly integrated into the host community, their environment is dominated mainly by focus on the performance of gender and family roles. In the minds of the respondents primarily religious values dominate, as opposed to the values of the secular state and civil society.

\subsection{Linguistic Cultural Orientation of Migrant Women}

The study showed that the vast majority of respondents in all groups consider their national language as native (100\% of Uzbek, $97.1 \%$ of Azerbaijani, $94.3 \%$ of Kyrgyz and Tajik women). The national language is also dominant in intra-family communication: I.: "What language do you use when speaking with your grandchildren?" P.: "Uzbek, because they are still small, when they grow up and go to school, we'll learn Russian, maybe Tatar. Time will tell what to do and how"(female, Uzbek, 55 y.o.).

In our opinion, the national language is not only the most popular language of social communication for migrant women, but also has a marking the ethnicity function.

Linguistic cultural degree of competence is different in the groups surveyed. The number of respondents who can speak only national language is high among Uzbek and Azerbaijani women (50\% and 46.7\%, respectively). There were $11.4 \%$ such respondents among Kyrgyz, 5.7\% - among Tajik women. A significant proportion of respondents characterized their linguistic competence as bilingual, including knowledge of predominantly national and Russian languages. Thus, the proportion of respondents who know their national and Russian languages is $46.7 \%$ of Uzbek, $32.9 \%$ of Kyrgyz, $24.3 \%$ of Azerbaijani and $50 \%$ of Tajik women. The number of respondents who indicate that they know national, Russian and Tatar languages was 30\% among Kyrgyz, 24.3\% of Tajik, $17.1 \%$ of Azerbaijani women. The number of Uzbek women with such abilities was insignificant $(2.2 \%)$.

Thus, the analysis of linguistic cultural orientations of respondents shows that the interviewed migrant women tend to have command of and every day use of the national language. The current situation in linguistic-cultural communication involves mainly the national language in mono-ethnic environment and narrows the range of social contacts of migrant women.

\subsection{The Level of Religiousness among Migrant Women}

The religious factor is one of the most difficult and controversial aspects of life strategies of migrant women. Most of the respondents consider themselves religious people (71.1\% of Uzbek, $71.4 \%$ of Azerbaijani, $68.7 \%$ of Kyrgyz and 58.6\% of Tajik women). A fifth of Azerbaijani and a sixth of Kyrgyz and Tajik women identified themselves as non-religious people. It should be noted that for a significant number of women in all groups surveyed it was difficult to identify themselves as religious. To the question: "Do you consider yourself a religious person?" $28.9 \%$ of Uzbek, $22.9 \%$ of Tajik, $15.7 \%$ of Kyrgyz and $7.1 \%$ of Azerbaijani women didn't know what to say.

The question "Do you agree with the phrase: "My religion is the best one"?" has also caused a mixed reaction among respondents. Uzbek respondents, in particular, could not definitely answer to this question: among them, $80 \%$ of them said that the question is difficult to answer. About third of Kyrgyz, Azerbaijani and Tajik women said the same.

Perception of their religion as the only true one, is mainly typical for Azerbaijani and Tajik respondents. Thus, $60 \%$ of Azerbaijani and every other of Tajik respondents agree with the statement: "My religion is the best one." About $30 \%$ of Kyrgyz and $12 \%$ of Uzbek respondents share this opinion.

A little less than fourth of respondents expressed the view that it was incorrect to consider one's religion as the only correct one. Most often this position was held by Kyrgyz respondents. Among them, fourth of women surveyed disagreed with the proposed expression. Fifth of Tajik women are also of the opinion that it is biased and unethical to consider one's religion as most appropriate. 10\% of Azerbaijani and only 5\% of Uzbek women agreed with this opinion.

Some difficulties were caused among migrant women by other proposed saying: "When science and religion are in conflict, is religion right?" As with the previous question, Uzbek women appeared the numerous ones finding 
it difficult to answer: $90 \%$ of respondents could not give a definite answer to the question. Every second of Kyrgyz and third of Azerbaijani and Tajik women felt the same. Priority of religion over science is recognized by every second of Azerbaijani and every third of Tajik women among the respondents. Disagreement with the proposed statement is most often expressed by Kyrgyz respondents: $40 \%$ of them believe that in the case of conflict between religion and science, preference should be given to science.

Thus, these data allow us to estimate the level of religiousness of migrant women as high. But for a significant number of migrant women it's difficult to answer questions related to the evaluation of their own religious identity. This may indicate that religiousness of women interviewed is to a certain extent of "theatrical" character, not a result of a conscious individual choice. However, it should be said about a significant proportion of respondents who are likely to perceive their religion as the only true.

According to the study, the majority of migrant women do not experience difficulties in the implementation of their religious life in Tatarstan. $96.7 \%$ of Uzbek, $87.1 \%$ of Kyrgyz, $84.3 \%$ of Tajik and $71.4 \%$ of Azerbaijani women expressed satisfaction with the religious situation in Tatarstan. One in ten of Azerbaijani and one in eight of Tajik respondents said about the difficulties encountered in the implementation of the religious life. Fourth of Azerbaijani respondents said that occasionally they had difficulties in their religious lives, and $5 \%$ believe that they are constantly in the complex religious situation in the region. $15 \%$ of Tajik women said that they encounter difficulties in carrying out their religious life sometimes.

The research has shown that the complexity of the implementation of religious life is only partly dependent on the period of residence of the respondents in Tatarstan. So, occasional difficulties in carrying out their religious life often experienced by women migrants residing in the territory of Tatarstan for more than 10 years (about fourth of respondents). At the same time, women living in Tatarstan 1 to 5 years face constant difficulties, as a rule.

Most respondents preferred to refrain from specifying certain manifestations of religious difficulties. Those who commented the situation, said that difficulties are mainly related to lack of understanding of the essence of their religion by others, and biased attitude. In addition, some members of the Azerbaijani population correlate religious difficulties with a long distance from their homeland.

Regular visits to the mosque are practiced by about $10 \%$ of the respondents. Most often they are Tajik and Kyrgyz. One-fifth of the representatives of these ethnic groups regularly attend the mosque on Fridays. At the same time, about one-third of Kyrgyz and Tajik women say that they attend the mosque extremely rarely. Azerbaijani women are more common for occasional visits to the mosque (30\%) or in the extreme necessity (25\%). One in ten of Azerbaijani women regularly attends the mosque on Fridays. Low level of religious activity was recorded among Uzbek women, $80 \%$ of whom say that they do not go to the mosque. $40 \%$ of Tajik and Kyrgyz and one in ten of Azerbaijani women said the same.

According to the study, it is extremely important for migrant women to attend a particular mosque. For respondents determining factor is not the location of the mosque but the number of representatives of their nationality attending it. Thus, the Kul Sharif, Sultan and Marjani mosques are most attended by Azerbaijani and Kyrgyz women. The Gaile, Nurulla, Sultan, and Kul Sharif mosques are mostly attended by Tajik women. The Kul Sharif and Sultan mosques - by Uzbek women.

In general, religiousness of migrant women seems very contradictory phenomenon. Thus, representatives of Uzbek nationality often found it difficult to explain statements related to religious principles and least of all were inclined to attend a mosque as a last resort. However, according to the study, they consider themselves to be the most religious people: $70 \%$ of Uzbek women participated in the study responded positively to the question "Do you consider yourself a religious person?", another $30 \%$ were found it difficult what to say, but none of the respondents said unequivocally that she was not religious.

From the interview: "After all, when it was the Soviet Union times we studied, we were taught atheism. We were also taught that there was no God, here and there. But after all our parents were Muslims as well as our grandparents. They kept saying, "Well, whatever they say, you are and will be Muslims. All the same. Because there is conscience ... to admit, accept, feel ... I decided to keep uraza (fastening) this year" (female, Kyrgyz, 48 y.o.).

A large proportion of respondents who found it difficult to answer the proposed questions, as well as contradictory responses received can be explained by the fact that religiousness of migrant women is largely, as it was already mentioned, superficial, of "theatrical" character. In addition, these data suggest a predominantly conformist type of consciousness among migrant women, which is reflected in the difficulties to formulate their 
own views, estimate the attitude to the referred problems.

\subsection{Attitude to the Role of Religion in Society}

According to the study, migrant women approve of the interference of religion with world. First of all, it is typical for Azerbaijani and Uzbek women, the vast majority of which to some extent support regulation of society with the help of religious norms (100\% and $97.2 \%$, respectively). $88.6 \%$ of Kyrgyz and $77.1 \%$ of Tajik women think the same way. At the same time, the vast majority of Uzbek (almost 100\%), 53.9\% of Azerbaijani, $47.1 \%$ of Tajik and $42.9 \%$ of Kyrgyz women ( 6 to 10 points on 10 point scale, where 0 - society should not be governed by religious law, while 10 - necessity of religious rules) support the idea that social life should comply with religious norms as much as possible. About $40 \%$ of Tajik and one in two of Kyrgyz women believe that religious norms must act on a par with other regulators of social life. $14.3 \%$ of Kyrgyz and $20 \%$ of Tajik respondents are for a complete rejection of religious norms as a regulator of the life of society.

The absolute majority of Uzbek and Azerbaijani, $82.9 \%$ of Kyrgyz and $70 \%$ of Tajik women believe that the political system in Russia should be to some extent consistent with the principles of a religious state. At the same time, $85.5 \%$ of Uzbek, $52.9 \%$ of Azerbaijani, $34.2 \%$ of Tajik and $28.5 \%$ of Kyrgyz women believe that religious rules take precedence over secular ones (from 6 to 10 points on 10-point scale, where 0 - life of the state should not be governed by religious law, while 10 - there should be religious rules). Beside, every tenth of Azerbaijani and Tajik respondents believe that the political system of the Russian Federation should be based solely on the principles of a religious state.

It is worth saying that only Tajik and Kyrgyz respondents are not geared-up to accept the Russian Federation as a religious state. $27.1 \%$ of Tajik and $15.7 \%$ of Kyrgyz women are for priority of secular norms.

Thus, according to most respondents, the political system of Russia should be based primarily on the principles of a religious state.

While answering the question, what laws govern rather difficult situations, respondents' opinions divided: $40 \%$ of respondents opted for the official law of the Russian Federation, 30\% believe the traditional standards of their people are the best ones. Kyrgyz respondents are more inclined toward the legislation of the Russian Federation. $50 \%$ of them would prefer to be guided by the norms of the Russian legislation in a difficult situation.

Tajik respondents also give priority to the Russian laws: $40 \%$ of them believe the best choice is to live according to the official legislation.

The vast majority of Uzbek respondents recognize the priority of traditional norms of their people. When having points at issue $60 \%$ of Uzbek women would refer to the principles of common law rather than to a state law. $20 \%$ of Kyrgyz, $20 \%$ of Azerbaijani and $10 \%$ of Uzbek respondents support this idea.

The desire to be guided by religious norms is more characteristic of Tajik respondents. $20 \%$ of them were in favor of the priority of religious principles. 10\% of Kyrgyz and 15\% of Azerbaijani women share this view. None of Uzbek respondents gave priority to religious norms.

To sum up, it should be noted that the analysis of social contacts of the respondents shows that the dominant strategy among migrant women is the pursuit of a mono-ethnic interaction. Statements about the existence of friendly relations with the local population are largely declarative in nature, because they do not consider it in a critical situation. The identity is dominated by a religious component and roles of family positioning for representatives of all groups under study. Migrant women emphasize their religiousness and often demonstrate the priority of the religious component over other components of identity. At the same time, a significant number of migrant women experience difficulties in having to answer questions related to the evaluation of their own religious identity. This may indicate that religiousness of women interviewed is to a certain extent of "theatrical" character, not a result of a conscious individual choice. But, it should be noted that many of respondents recognize their own religion as the only true.

\section{Discussions}

Studies of female labor migration are considered by several disciplines. Demographers are engaged in statistical analysis of migration flows. First of all they are interested in the contribution of migration to the demographic processes (reproduction and overall population growth) and changes in the structure of the population and its characteristics (aging, gender balance, life expectancy, the structure of diseases, etc.) (Chudinovskikh, 2004). Most of the migrants belong to the category of the working population and play a significant role in the labor market human resources. In this regard, professional, age and sex structure of migration flows is of great interest to economists. The subject of economic analysis is the contribution of migrants to the GDP of countries of origin 
and of host countries, the direction of movement of migrants (to Russian, to foreign countries, between regions), the transformation of economic sectors, which employ a significant number of migrants, and economic mechanisms of regulation of migration (Titarenko, 2013; Tyuryukanova, 2004; Ilimbetova, 2013). Another aspect of labor migration of women is the legal status of migrants and migration policy. Legislative initiatives that directly affect the everyday and professional lives of the migrant in the host country are introduced regularly. Deciding on the form of migration - either legal or illegal - imposes a specific imprint not only on the type of employment, but also on the living conditions of a person who decides to go to work. Recurrent problems with the police, failure to seek medical attention, difficulty in placement of children in schools and kindergartens, the lack of information make legal migrants, especially women, vulnerable and completely deprived of rights (Female migrants from the CIS countries in Russia, 2011; Korchagin, 2010; Kolosov, 2004; Tyuryukanova, 2004). Under these conditions informal relationships become of particular importance - family ties, communities, sustainable communities of neighbors. Studies of everyday practices of migrants are of anthropologists and sociologists interest. Primarily the analysis is focused on internal and external factors of migration (the so-called push- and pull- factors). The authors refer to the mechanisms of migration - the way people choose the strategy of moving, what type of residence (short or long) they target, what resources are required to implement the move, which communication channels are used to maintain relationships with family and within the community. Considerable attention is paid to the issues of adaptation and characteristics of the host society - how high is the level of xenophobia in countries where migrants go to work; are there mechanisms of adaptation and integration of newcomers, etc. (Brednikova, 2003; Ilimbetova, 2013). Many scholars, including psychologists, refer to the study of the experience of migrant women (Grishunina, 2011). However, the study of life strategies in the biographies of migrant women in the regions of the Russian Federation requires closer examination. In this study, a group of authors considered ethno-cultural and religious practices among migrant women in the Republic of Tatarstan.

\section{Conclusion}

Summing up, we can draw the following conclusions:

- Analysis of the social contacts of the respondents reveals a high degree of intra-group consolidation among the groups under study. For most of the women interviewed, regardless of the length of residence in the region, the scope of social contacts is limited to the relatives. Analysis of the friendly relations of the respondents also confirms that the majority of them are focused on social contacts in monocultural environment. Contacts with the local population are mainly due to the joint work. The majority of respondents (primarily Uzbek and Azerbaijani women), expressed disapproval of the possibility of the marriage of their relative with a representative of a different nationality. These trends indicate the orientation of the female respondents primarily on mono-ethnic social interaction.

The representatives of all groups in the structure are characterized by the dominance of the religious component of identity and roles of family positioning. Civil and professional aspects of identity of the majority of respondents are not expressed or weak. At the same time the religious component of identity in most actualized among Uzbek women (more than $90 \%$ of respondents), and it is actualized among about $50 \%$ of Armenian and Tajik women. The professional component of identity is most represented among the Azerbaijani diaspora, suggesting greater integration into the host community.

- The study showed that for the majority of respondents in all groups a national language plays an important role as a welding factor. The primary means of communication for the majority of the respondents is the national language.

\section{Recommendations}

The article may have scientific and humanitarian and practical significance. It may appear useful for specialists in the social sciences: ethnologists, social and cultural anthropologists, political scientists, and representatives of the bodies supervising migration policy and inter-ethnic cooperation.

\section{Acknowledgments}

The work is performed according to the Russian Government Program of Competitive Growth of Kazan Federal University

\section{References}

Abashin, S. (2007-2008). Ekonomicheskie migranty iz Tsentralnoy Azii: issledovanie transformatsii identichnosti, norm povedeniya i tipov sotsialnykh svyazey. Sankt-Peterburg. 
Brednikova, O. (2003). Zhenskaya trudovaya migratsiya: smena gendernykh kontaktov? Gendernye otnosheniya $v$ sovremennoy Rossii: issledovaniya 1990-kh gg. Samara: Izd-vo "Samarsky universitet".

Chudinovskikh, O. (2004). Prichiny I posledstviya krizisa rossiyskoy migratsionnoy statistiki. Otechestvennye zapiski, 4, 176-190.

Grishunina, E. V. (2011). Kognitivno-emotsionalnaya struktura perezhivaniy slozhnykh zhiznennykh situatsiy. Konsultativnaya psikhologiya i psikhoterapiya, 4, 130-152.

Ilimbetova, A. A. (2013). Zhenshchiny-migranty na rossiyskom rynke truda. Vestnik altaiskoy akademii ekonomiki i prava, 2, 25-29.

Kolosov, S. A. (2004). Manipulyativnye strategii diskursa nenavisti. Kritika i semiotika, 7, 248-256.

Korchagin, A. G. (2010). Migratsionnaya politika v reshenii migratsionnykh problem v Rossii. Pravo i politika, 6, 1063-1071.

Titarenko, L. (2013). Zhenskaya migratsiya na Vostok i Zapad: sluchay Belarusi. Poyasnitelnaya zapiska 13/92. Minsk.

Tyuryukanova, E. (2000). Trudovaya migratsiya zhenshchin iz Rossii: legalnye i nelegalnye formy. Moskva.

Tyuryukanova, E. (2004). Trudovaya migratsiya v Rossiyu. Otechestvennye zapiski, 4, 53-68.

Zhenshchiny-migranty iz stran SNG v Rossii (2011). Moskva: Maks-Press.

\section{Copyrights}

Copyright for this article is retained by the author(s), with first publication rights granted to the journal.

This is an open-access article distributed under the terms and conditions of the Creative Commons Attribution license (http://creativecommons.org/licenses/by/3.0/). 